\title{
Predictors of the Use of Traditional Medicines in the Universal Health Coverage System in Indonesia
}

\author{
Yen Yen Sally Rahayu ${ }^{1}$, Tetsuya Araki $^{1} \&$ Dian Rosleine ${ }^{2}$ \\ ${ }^{1}$ Department of Global Agricultural Sciences, Graduate School of Agricultural and Life Science, The University \\ of Tokyo, Japan \\ ${ }^{2}$ Ecology Research Group, School of Life Sciences and Technology, Institut Teknologi Bandung, Indonesia \\ Correspondence: Yen Yen Sally Rahayu, Department of Global Agricultural Sciences, Graduate School of \\ Agricultural and Life Science, The University of Tokyo, 1-1-1 Yayoi Bunkyo Ward Tokyo 113-8657, Japan.
}

Received: March 25, 2021 Accepted: April 21, 2021 Online Published: April 26, 2021

doi:10.5539/gjhs.v13n6p24 URL: https://doi.org/10.5539/gjhs.v13n6p24

\begin{abstract}
Background: Indonesia has committed to achieving Universal Health Coverage (UHC) and introduced national health insurance $(\mathrm{JKN})$ to meet that commitment. Despite the increasing availability of healthcare services under the JKN scheme, traditional medicine (TM) continues to be a significant part of healthcare for Indonesians. In the context of the UHC system, this study aims to examine the predictors of TM use among urban and rural communities in Indonesia.
\end{abstract}

Methods: A cross-sectional survey was conducted using a semi-structured questionnaire targeting urban and rural communities. A total of 926 households were randomly selected to participate in the survey. Multivariate logistic regression analysis was used to identify the significant predictors of TM use.

Results: Multivariate analysis revealed the following variables to be predictive of TM use, namely, rural residence, being more educated, experiencing some health problem, demonstrating ethnomedical knowledge, having a favourable opinion about the safety and efficacy of TM and holistic orientation to health. On the other hand, working in the formal sector was associated with lower odds of using TM compared to those who were employed in the informal sector.

Conclusion: People's experience, personal attributes, and attitude towards TM, rather than dissatisfaction with healthcare service, predicted the likelihood of using TM in the UHC system in Indonesia. This finding also implies the underutilisation of JKN services by the insured TM users living in rural areas. Considering the community's strong preferences for TM, this paper argues that its inclusion in the JKN system may increase the utilisation of the JKN service.

Keywords: traditional medicine; predictors; Indonesia; universal health coverage (UHC); healthcare utilization

\section{Introduction}

The use of traditional medicine (TM) in primary health care has been endorsed to compensate for the insufficient penetration of biomedicine, especially in remote or marginalized areas in developing countries (WHO, 1978). On the other hand, global economic growth and international initiatives have greatly promoted advances in medicine and increased the availability of biomedicine. Particularly in the last two decades, commitment to universal health coverage (UHC) has generated intense global action to provide biomedicine-based healthcare services (WHO, 2013). Indonesia has launched a national insurance scheme within the UHC framework called the Jaminan Kesehatan Nasional (JKN, National Health Insurance). Currently, nearly 223 million Indonesians are members of the JKN, which accounts for $82.4 \%$ of the total population (Kasumaningrum, 2019). Healthcare service utilization, with an average of 400,000 visitations in a year, has increased by $77.8 \%$ in two years since it was launched, (BPJS Health, 2019).

Indonesia has a history of reliance on various forms of TM (Chaerani \& Amar, 2010; Elfahmi et al., 2014; Jennifer \& Saptutyningsih, 2015; Pengpid \& Peltzer, 2018; Supardi et al., 2011), including diverse health practices, approaches, knowledge, and beliefs. These incorporate plants, animal, and/or mineral-based medicines, spiritual therapies, manual techniques and exercises applied singly or in combination to maintain well-being, as well as to prevent, diagnose or treat illness (WHO, 2000). Despite the increasing provision of healthcare services under the 
UHC, TM continues to be a significant aspect of healthcare for Indonesians. A recent national survey reported that $44.3 \%$ of households in Indonesia utilized TM of these, $79.8 \%$ used herbal remedies and $69.3 \%$ used forms of manual treatment, including spiritual healing (MoH of Indonesia, 2018). While self-made and self-applied healing techniques are common, TM products and services are also commercially available. In 2018, 31.4\% of Indonesian households used the paid services of TM, 44.3\% of households utilized TM, and $48 \%$ bought commercial/ready-made herbal medicines (MoH of Indonesia, 2020).

When faced with the pervasive use of TM and the fact that people seem willing to pay for these products and services even though they were covered by health insurance, one asks, what are the factors underlying a person's decision to use TM? Various explanations and motivations have been proposed to explain the use of TM. According to the behavioural model, the use of healthcare is a function of population characteristics categorized into three types of factors; predisposing, enabling, and need (Aday \& Andersen, 2005). In the context of TM use, predisposing factors may include demographic factors (female gender, old age (Bishop \& Lewith, 2010; Hughes et al., 2013; Pengpid \& Peltzer, 2018), ethnicity (Aziz \& Tey, 2009; Kuo et al., 2004; Trotter, 1981), psychosocial factors (cultural attitudes, belief system (Astin, 1998; R. M. Gyasi et al., 2016; Hollenberg et al., 2013; Sato \& Costa-i-Font, 2012), perceived efficacy, side effects and quality of TM (Clement et al., 2007; R. M. Gyasi et al., 2011)). Examples of enabling factors include socio-economic factors, such as education, income, the nature of occupation, urban or rural residence and insurance status (Allabi et al., 2011; R. Gyasi et al., 2018; Peltzer et al., 2016; Pengpid \& Peltzer, 2018; Picking et al., 2011). Need factors may include, health-related factors (chronic disease, poor physical and mental health (Astin, 1998; James et al., 2019; Kelner \& Wellman, 1997; Liebert, 1998; Wiles \& Rosenberg, 2001)), inadequate health care access (Wilson et al., 2012) and issues of satisfaction with conventional treatment (Furnham \& Kirkcaldy, 1996; Mcgregor \& Peay, 1996; Vincent \& Furnham, 1996).

At present, in the context of the UHC system in Indonesia, there is a lack of comprehensive analysis on the correlations among the factors relevant to the use of TM. Accordingly, considering the predisposing, enabling, and need factors, this study aims to examine factors predicting the likelihood of using TM, which might account for the pervasive use of TM among the rural and urban communities in the UHC system in Indonesia.

\section{Methods}

\subsection{Study Location and Data Collection}

We conducted a cross-sectional household survey covering both rural and urban areas in the province of West Java on Java Island, where the central government is located. Economically, it is the most developed area in Indonesia. Consequently, the healthcare services and facilities are more widespread than on other islands of Indonesia. The ratio of JKN subscribers in West Java reached $84 \%$ of the total population in 2019, which placed it among the regions with the largest number of subscribers (Kasumaningrum, 2019). At the same time, West Java is also one of the top four provinces with the most TM users (MoH of Indonesia, 2010). West Java was selected deliberately because the region seems to provide ambivalent conditions for choosing health care methods. While there is sufficient provision of healthcare services and a high number of JKN subscribers, there is also a high prevalence of TM users. Thus, it provides an ideal environment in which to identify the determinants for the use of TM when access to healthcare service within the UHC system is more easily available than elsewhere.

Several rural and urban areas in the region were selected to represent various geographical, demographic, and socioeconomic situations in the region. The data were collected during eight months spread over 2018 and 2019. A total of 926 households, 473 in the rural areas and 453 in the urban areas, were selected to be included in the household survey with the necessary permission from the local authority. The households were chosen randomly by drawing a number assigned to each hamlet in the district or village. One adult member (over 15 years old) from each household was selected at random and interviewed using a semi-structured questionnaire to gather information on socio-demographic characteristics, health problems, healthcare service access, and satisfaction level with healthcare service. The participants were asked about their knowledge of medicinal plants, perceived efficacy and safety of TM compared to conventional medicine, and their belief in, or philosophical view of health. In-depth interviews were subsequently conducted with survey participants who agreed to be further interviewed to elaborate on their answers to the questionnaire. A total of sixteen Indonesian interviewers were recruited and trained by the first author on the data collection process to undertake the exercise. Before starting the interview, the nature, and the purpose of the research were explained and then verbal consent from each respondent was obtained. Interviews were conducted in Sundanese and Indonesian languages and transcribed into English by the first author, an Indonesian and a native Sundanese.

In this study context, the term 'traditional medicine' (TM) was used interchangeably with traditional healthcare and included any form of unconventional medicines/treatment commonly practiced in Indonesia. TM used by the 
study population included product and service, both self-prepared/self-treated and commercially available. Following (MoH of Indonesia, 2013), TM used in this study was categorized based on the method applied: 1) herbal-based medicines (jamu) made by individual or industry (ready-made/instant), and 2) manual-technique-based treatment including practices involving the use of some tools (e.g., acupuncture, bekam (cupping), acupressure), without tools (e.g., massage, bone setting) and spiritual healing (e.g., rukiyah, dukun/shaman/faith healer). The term conventional medicine (CM) was used interchangeably for conventional treatment and included biomedicine/ drug, healthcare service based on biomedicine.

\subsection{Variables and Statistical Analysis}

The dependent variable, TM use, was operationalised as use of TM in the past 12 months. The variable was a dichotomous measure coded as 0 (no use) and 1 (use). In the behavioural model of healthcare utilization (Aday \& Andersen, 2005), it is assumed that people's use of healthcare is a function of their predisposition to use (predisposing variables), factors that enable or impede use (enabling variables), and their need for care (need variables). Accordingly, independent variables of possible predictors of TM use in the context of this study were selected and categorized as follows:

1. Predisposing factors: age and sex (as demographic variables); ethnomedical knowledge, health belief, perceived efficacy, and safety of TM (as psychosocial variables)

2. Enabling factors: level of education, residential status, nature of occupation, household income level, and JKN status (as socio-economic variables)

3. Need factors: health problem, a perceived problem in accessing healthcare service, and satisfaction level with healthcare service.

Independent variables were operationalized and coded as indicated in Table 1 below.

Table 1. Operationalisation and coding of independent variables

\begin{tabular}{|c|c|c|}
\hline Independent Variable & Operational definition & Coding \\
\hline \multicolumn{3}{|l|}{ Predisposing Factors } \\
\hline Gender & Being male or female & $0=$ Male $; 1=$ Female \\
\hline Age & Number years of life & ${ }^{*} 0=\leq 20 ; 1=21-39 ; 2=\geq 40$ \\
\hline Perception of TM quality & $\begin{array}{l}\text { TM efficacy and safety are equal or better than } \\
\text { conventional treatment }\end{array}$ & ${ }^{*} 0=\mathrm{No} ; 1=\mathrm{Yes}$ \\
\hline Belief system & $\begin{array}{l}\text { Perceived that health of body, mind, and spirit are } \\
\text { related (holistic orientation) }\end{array}$ & ${ }^{*} 0=$ No; $1=$ Yes \\
\hline Ethnomedical knowledge & $\begin{array}{l}\text { Demonstrated traditional knowledge of medicinal } \\
\text { plants (the most widely used for TM in the study), } \\
\text { which assessed through questions regarding the most } \\
\text { frequently used medicinal plants and use purpose. The } \\
\text { participants considered demonstrating ethnomedical } \\
\text { knowledge if they cited at least one type of plant and } \\
\text { its medicinal purpose. }\end{array}$ & ${ }^{*} 0=$ No; $1=$ Yes \\
\hline \multicolumn{3}{|l|}{ Enabling Factors } \\
\hline Residence & Being rural or urban resident & ${ }^{*} 0=$ Rural; $1=$ Urban \\
\hline Education level & Highest level of education completed & $\begin{array}{l}{ }^{*} 0=\text { Elementary or lower; } 1= \\
\text { Secondary; } 2=\text { High school; } 3= \\
\text { College or more }\end{array}$ \\
\hline Occupation & Economic activity that generates income & $\begin{array}{l}{ }^{*} 0=\text { Informal; } 1=\text { Formal; } 2=\text { Student; } \\
3=\text { Other }\end{array}$ \\
\hline Household income & Income of household per month & $\begin{array}{l}0=\mathrm{IDR} 2000 \mathrm{~K} \text { or less; } 1=\mathrm{IDR} \\
2100 \mathrm{~K}-5000 \mathrm{~K} ; 2=\text { More than IDR } 5 \mathrm{~K}\end{array}$ \\
\hline National Health Insurance & Being insured by the JKN & ${ }^{*} 0=$ No; $1=$ Yes \\
\hline
\end{tabular}




\begin{tabular}{|c|c|c|}
\hline \multicolumn{3}{|l|}{ Need Factors } \\
\hline Health problem & $\begin{array}{l}\text { Experienced health problem during the previous } 12 \\
\text { months. }\end{array}$ & ${ }^{*} 0=\mathrm{No} ; 1=\mathrm{Yes}$ \\
\hline $\begin{array}{l}\text { Problem of healthcare } \\
\text { service access }\end{array}$ & $\begin{array}{l}\text { Perceived access to healthcare to be a problem in their } \\
\text { community. }\end{array}$ & ${ }^{*} 0=\mathrm{No} ; 1=\mathrm{Yes}$ \\
\hline \multirow{5}{*}{$\begin{array}{l}\text { Satisfaction level with } \\
\text { healthcare service }\end{array}$} & \multirow{5}{*}{ Defined as perceived by participants. } & $0=$ Dissatisfied \\
\hline & & 1= Somewhat dissatisfied; \\
\hline & & $2=$ Neither satisfied nor dissatisfied; \\
\hline & & $3=$ Somewhat satisfied; \\
\hline & & $4=$ Satisfied \\
\hline
\end{tabular}

${ }^{*}$ Reference group in multivariate analysis.

Data analysis was conducted using SPSS version 11.0 statistical software. The analysis was conducted using descriptive statistics, frequency distributions, Chi-square analysis, and binary logistic regression analysis. Only factors found to be significant in Chi-square analysis were included in the logistic regression analysis table. The conventional $p<0.05$ level was used to determine statistical significance.

\section{Results}

\subsection{Socio-Demographic Characteristics}

A total of 926 people participated in the study: 473 (51.1\%) from rural communities and 453 (48.9\%) from urban communities. The majority of participants were female (58.7\%), aged 40 years or over $(55.8 \%)$, and had an education of primary school level or lower $(47.5 \%)$. Two-thirds of the total study population (636 participants) were covered by JKN. Most participants were engaged in the informal sector $(82.5 \%)$. Low-income participants (monthly incomes less than IDR 2000K (US\$140)) constituted $50.6 \%$ of the sample. The majority of participants $(85.3 \%)$ had experienced health problems during the preceding 12 months. The most frequently reported illnesses were fever, hypertension, gastritis, and rheumatic diseases. Most participants (79.5\%) did not perceive that any problem existed with access to healthcare services. In response to the question regarding the degree of satisfaction with healthcare services, most participants (71.2 \%) said they were 'neither satisfied nor dissatisfied', followed by 'somewhat satisfied' (17.8\%) and 'somewhat dissatisfied' (9.3\%).

\subsection{Knowledge, Perception, and Attitude Related to TM Practice}

Participants, who used some form of TM in the previous year, comprised $69.8 \%$ (646) of the total number of respondents. Overall, the majority of individuals had a positive perception of the efficacy and safety of TM. TM safety and efficacy were perceived equal or better compared to CM by $73.3 \%$ (679) of participants. Most participants (72.7\%) held a holistic view of health ("the health of my body, mind, and spirit are related").

The most used four TM categories were homemade herbal medicines - which included single-ingredient and mixture concoctions/jamu (55.7\%), massage (14.8\%), industrial (instant) herbal medicines - including jamu and supplements $(12.3 \%)$; and the bone-setters $(7.5 \%)$. The majority of participants $(82.1 \%)$ demonstrated knowledge of traditional herbal medicine (i.e., knowing at least one medicinal plant and its medicinal purpose), with the most frequently cited being Curcuma longa (koneng), Zingiber officinale (jahe), Momordica charantia (paria), Erythrina subumbrans (dadap) and Psidium guajava (jambu batu), and decoction prepared by the most commonly used method. Of 39 cited health problems treated with TM, the most frequently cited were digestion related problems (13.5\%), headaches and common cold (both $12.7 \%$ ), cough $(8.9 \%)$, muscle-related problems (7.7\%), fever and toothache (5.4\%), and hypertension (4.6\%). 
3.3 Associates and Predictors of TM Use in Bivariate and Multivariate Analyses

Table 2. Characteristic of participants by traditional medicines use status $(\mathrm{n}=926)$.

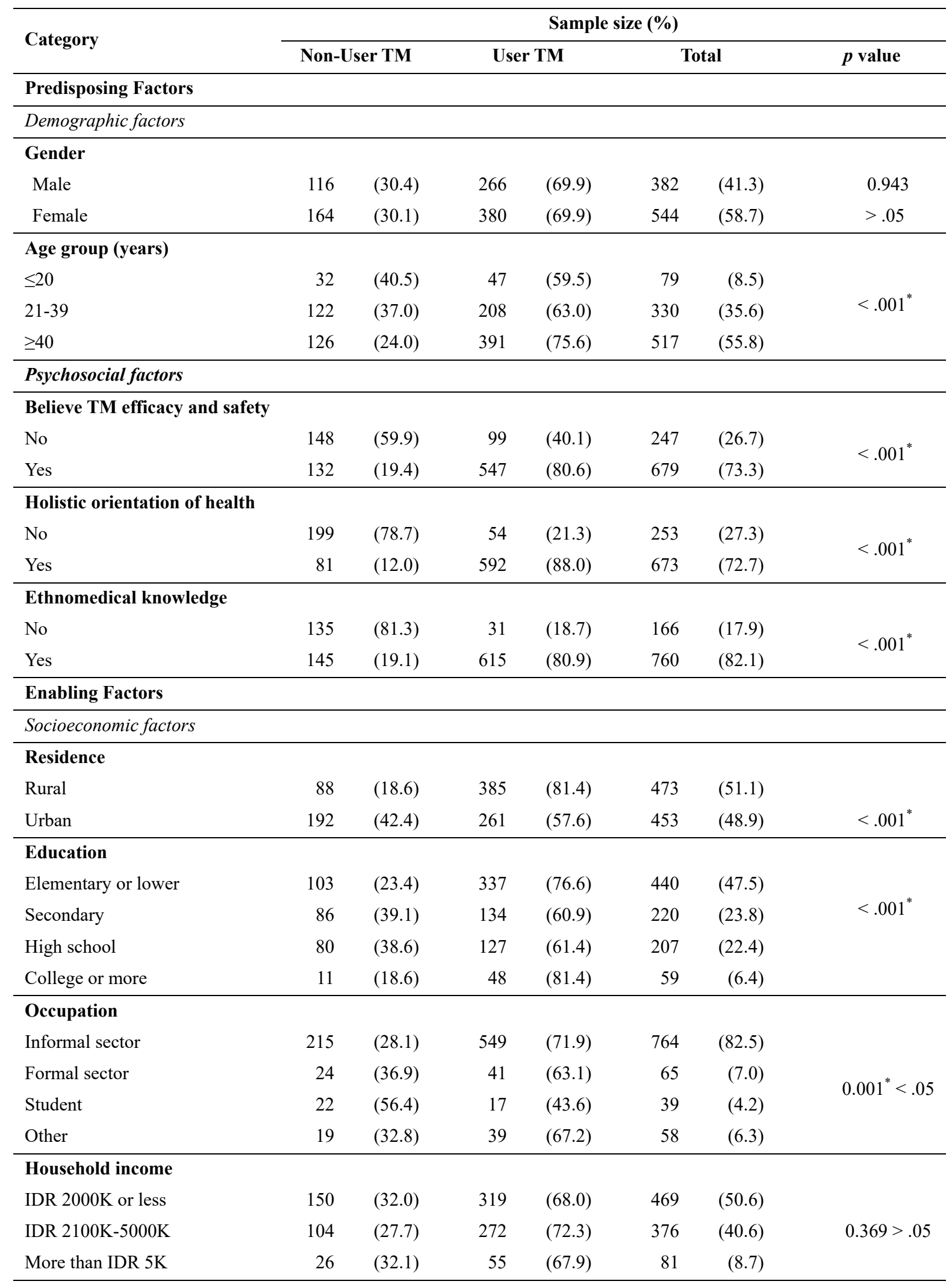




\begin{tabular}{lrrrrrrr}
\hline National Health Insurance (JKN) & & & & & & & \\
No & 112 & $(38.6)$ & 178 & $(61.4)$ & 290 & $(31.3)$ & $<.001^{*}$ \\
Yes & 168 & $(26.4)$ & 468 & $(73.6)$ & 636 & $(68.7)$ & \\
\hline Need Factors & & & & & & & \\
\hline Health problem & & & & & & & \\
No & 63 & $(46.3)$ & 73 & $(53.7)$ & 136 & $(14.7)$ & $<.001^{*}$ \\
Yes & 217 & $(27.5)$ & 573 & $(72.5)$ & 790 & $(85.3)$ & \\
\hline Problem to access healthcare service & & & & & & & \\
No & 166 & $(22.6)$ & 570 & $(77.4)$ & 736 & $(79.5)$ & \\
Yes & 114 & $(60.0)$ & 76 & $(40.0)$ & 190 & $(20.5)$ & \\
\hline Satisfaction with healthcare service & & & & & & & \\
Dissatisfied & 2 & $(25.0)$ & 6 & $(75.0)$ & 8 & $(0.9)$ & \\
Somewhat dissatisfied & 29 & $(33.7)$ & 57 & $(66.3)$ & 86 & $(9.3)$ & $0.832>.05$ \\
Neither satisfied nor dissatisfied & 193 & $(29.3)$ & 466 & $(70.7)$ & 659 & $(71.2)$ & \\
Somewhat satisfied & 54 & $(32.7)$ & 111 & $(67.3)$ & 165 & $(17.8)$ & \\
Satisfied & 2 & $(25.0)$ & 6 & $(75.0)$ & 8 & $(0.9)$ & \\
\hline *Stastical sigfin
\end{tabular}

${ }^{*}$ Statistical significance, $\mathrm{p}<.05$.

Table 2 shows the results of bivariate and chi-square analyses of TM use and each of the predisposing, enabling, and need factors. A statistically significant response was found for most variables. TM use was associated with age (40 years and older), favourable perception of TM safety and efficacy, holistic orientation to health, having ethnomedical knowledge, area of residence (rural), education (low), occupation (informal), health insurance status (enrolled), having experienced health problem during the preceding one year, and access to healthcare service not perceived as a problem. Gender ( $p=0.943)$, household income $(p=0.369)$, and satisfaction level $(p=0.832)$ with healthcare service were not statistically significant indicators of TM use, thus were not included in the subsequent multivariate analysis.

Table 3. Significant predictors of TM use in the binary logistic regression $(\mathrm{n}=926)$.

\begin{tabular}{lcccc}
\hline \multicolumn{1}{c}{ Variable } & Coefficient & $\boldsymbol{p ~ v a l u e ~}$ & \multicolumn{2}{c}{ Odds Ratio $^{*}$} \\
\hline Residence & -1.844 & $<.001$ & 0.158 & $(0.10-0.26)$ \\
Occupation (formal) & -1.26 & 0.001 & 0.284 & $(0.13-0.61)$ \\
Education (college or more) & 2.436 & $<.001$ & 11.42 & $(3.62-36.06)$ \\
Believe in TM safety and efficacy & 0.839 & 0.001 & 2.313 & $(1.42-3.77)$ \\
Health problem & 0.758 & 0.007 & 2.135 & $(1.231-3.70)$ \\
Holistic orientation to health & 2.474 & $<.001$ & 11.87 & $(7.2-19.56)$ \\
Ethnomedical knowledge & 1.87 & $<.001$ & 6.485 & $(3.35-12.54)$ \\
\hline
\end{tabular}

${ }^{*} 95 \%$ Confidence Interval.

Table 3 shows multivariate analysis results using binary logistic regression of ten significant variables in the bivariate analysis. The test of the full model against a constant only model was statistically significant, indicating that the predictors, as a set, reliably distinguished between TM users and the non-users (chi-square $=510.439, \mathrm{p}$ $<.001$ with $\mathrm{df}=11$ ). The model has a Cox and Snell $\mathrm{R}^{2}=0.424$ and Nagelkerke $\mathrm{R}^{2}=0.600$, which means that it can explain $42 \%-60 \%$ the variability in the odds of using TM.

The following variables made significant contributions to the prediction model: area of residence, occupation, education, belief in the safety and efficacy of TM, health problem, holistic view of health, and ethnomedical knowledge. While participants residing in a rural location $(p<.001)$ and being more educated $(p<.001)$ were likely to use TM, those working in the formal sector were less likely to use TM $(\mathrm{p}=0.001)$. Participants who 
perceived TM safety and efficacy to be equal or better than CM were associated with using TM $(p=0.001)$. Those who reported having experienced health problems in the past year were almost two times more likely to use TM (p $=0.007)$. Participants holding holistic orientation to health $(p<.001)$ and possessing traditional knowledge of herbal medicine $(\mathrm{p}<.001)$ had higher odds of using TM. Although age, perception about access to healthcare service, and JKN enrolment were statistically significant in bivariate, chi-square analysis; those aged 40 and more opined that access to healthcare service was not a problem and even though they had been insured, they were more likely to use TM, these three variables were not highly significant in predicting TM use in the multivariate model.

\section{Discussion}

\subsection{Prevalence of TM Use}

The present study examined predictors of TM use and was the first study to be carried out in the context of the Indonesian UHC system. In this study, we targeted the general population in rural and urban communities. The results revealed that TM use is common among the studied population because more than half of them (69.8\%) used it in the previous year. The prevalence of TM use in this study is higher than that reported in the recent national survey. In it, $44.2 \%$ of households in Indonesia were found to have used TM (MoH of Indonesia, 2018). However, the pattern of the most frequently used type of TM is similar to that found in this study, that is the type used by the majority of users was herbal medicine-based. West Java was reported as one of the top four provinces with the most herbal medicine/jamu users (Rahayu et al., 2020), which probably contributes to the high prevalence of TM use in this study.

\subsection{The Significant Predictors of TM Use}

A clearer picture of TM users is generally revealed by the multivariate analysis. Factors found to predict TM use include the area of residence, occupation, education, health status, health belief, perception, and knowledge related to TM. Our bivariate analysis results agree with those of other studies (Bishop \& Lewith, 2010; Peltzer et al., 2016) in terms of the identified associations of socio-demographic characteristics with TM use. However, our multivariate analysis highlighted some differences, too. For example, age was found to be significantly associated with TM use in the bivariate analysis, however, no significant effect of age in the multivariate analysis. Previous studies have shown consistently that rural people were more likely to be users of TM than their urban counterparts (Bishop \& Lewith, 2010; Delgoda et al., 2004; Jennifer \& Saptutyningsih, 2015; Pengpid \& Peltzer, 2018), and our result is consistent with that finding. However, the common notion that widespread use of TM is attributable to poor access to health care services, especially in rural areas (Weckmüller et al., 2019) is not fully supported by this study. Primary health care (e.g., community health centres (puskesmas), midwives, and private clinics) are available and can be reached within an average of 15 minutes by motorcycle. This fact may affect perceived access to care as the majority of participants did not perceive a problem with access to healthcare service in their community. In this regard, residents of rural areas, from their individual points of view, may perceive access to local primary healthcare services as sufficient to satisfy them (Wilson et al., 2012). On the other hand, it was common for the rural community in this study to use their home garden or allotment land as the medium for the cultivation of medicinal plants. Thus, in this study, the easier access to TM in a rural area may explain the likelihood of rural participants to use TM (Sato \& Costa-i-Font, 2012).

The nature of occupation was a significant predictor of TM use. While the bivariate analysis showed that informal workers were more likely to use TM than those in other occupations, the multivariate analysis does not indicate that. However, working in the formal sector was associated with fewer odds in favour of using TM as compared with those working in the informal sector. The high prevalence of TM use among the workers in the informal sector in this study may be associated with being uninsured. The JKN rollout has brought out the "missing middle" problem in which the non-poor informal sectors have remained uncovered from the insurance due to the necessity of self-enrolment (Dartanto et al., 2015). Being uninsured may have prompted informal workers to resort to TM as a safety net for healthcare.

The utilization of TM in developing countries is generally associated with a lack of education (Agyemang-Duah et al., 2020; Bishop \& Lewith, 2010; R. M. Gyasi et al., 2015; Peltzer et al., 2016; Quinlan \& Quinlan, 2007). Thus, our finding that TM users tend to be better educated may be counterintuitive. The preference of educated people for more natural treatments with fewer side effects (Aziz \& Tey, 2009) may explain this. Along with the "back to nature" trend in lifestyle among people living in the city, there is also a growing trend of artisan ready-to-drink herbal (jamu) in Indonesia (Lim \& Pranata, 2020; Putro et al., 2020). Such high-end jamu product is seemingly popular among urban consumers who tend to have better education. Furthermore, education may increase the likelihood to use TM because educated people will be exposed to various traditional forms of health care through their reading on the subject (Astin, 1998). The majority of participants in this study demonstrated ethnomedical 
knowledge, and thus it is also possible that more educated people obtained such knowledge through their reading.

The multivariate analysis showed health status to be a predictor of TM use. The odds of being a TM user are about two times higher among those who experienced some health problem in the previous year. Since those in poor health may have had less success in treating their health problems with $\mathrm{CM}$, their continued suffering may have prompted them to seek traditional healthcare alternatives (Astin, 1998). Similarly, those with chronic illness and those who classify their sickness as 'serious' appear to have tried TM more than those with non-chronic illnesses and individuals who perceive their illnesses to be less serious (Sato \& Costa-i-Font, 2012).

Various studies have shown that psychosocial factors, such as cultural attitudes and beliefs, influence traditional healthcare use (R. M. Gyasi et al., 2015, 2016; Hollenberg et al., 2013; Lee et al., 2004; Sato \& Costa-i-Font, 2012). In this study, almost all the psychosocial factors related to TM practice were predictive of its use. The odds of someone using TM increase two-folds if the person considered safety and efficacy of TM favourably. Other studies (Astin, 1998; Caniago \& Siebert, 1998; Clement et al., 2007) have reported similar findings. The results of in-depth interviews confirmed that many participants considered the experienced of relief from symptoms as the determinant of the use of TM.

Our finding further showed that belief in a holistic philosophy of health strongly predicted the use of TM. Notably, many participants perceived TM to be more in line with their own beliefs and holistic view of health (i.e., belief in the relatedness of physical, spiritual, and mental health). They often described that TM is not only effective as preventive care but also for curative and rehabilitative reasons. It was also commonly believed that spiritual healing cured physical illness and brought about spiritual and mental well-being. TM users also tended to believe in the equal importance of body, mind, and spirit (Astin, 1998; R. M. Gyasi et al., 2016; Sato \& Costa-i-Font, 2012)It is not surprising that ethnomedical knowledge should facilitate TM practice in everyday healthcare (Weckmüller et al., 2019). In this study, such knowledge is also a significant predictor of TM use. The odds of those who demonstrated ethnomedical knowledge being users were about six times higher than those who lacked that knowledge. Compared to other forms, herbal medicine was the most frequently used TM in this study. The majority of participants showed knowledge of the traditional use of plants, including the plants' type, medicinal effect, and how to prepare home remedies from the plants. Having greater knowledge and extensive family history of such knowledge about medicinal plants were strongly predictive of practicing TM when the respondents were influenced by environmental factors and the access to modern health care was limited (Patwardhan et al., 2005).

\subsection{Influence of Healthcare Service within the UHC System on TM Use}

Variables related to the conventional healthcare in this study were not significant predictors of TM use. Although there was a trend in the direction of being more likely to use TM among those who were insured and did not perceive a problem with accessing health services, this variable was not a significant predictor of TM use as previously reported (Caniago \& Siebert, 1998; Toda et al., 2017; Vandebroek \& Balick, 2012). This finding supports our previous finding that there was no clear relationship between health insurance status and herbal medicines use among the rural population in West Java (Rahayu et al., 2020). Contrary to many previous findings (Avina \& Schneiderman, 1978; Lee et al., 2004; Mcgregor \& Peay, 1996; Schäfer et al., 2002), our finding also showed that a negative attitude toward healthcare service was not predictive of TM use. Among those who reported being satisfied with healthcare service (165), $67.3 \%$ used TM, while $66.3 \%$ of those who reported dissatisfaction (86) were TM users, indicating that TM users were no more dissatisfied with the service than nonusers were. Most of the insured TM users whose responses converged toward a neutral tone (neither dissatisfied nor satisfied), mainly comprised of rural residents, suggesting the possibility of underutilisation of JKN by this segment. This indicates that the health insurance has not effectively increased healthcare service utilization as intended, particularly by the most vulnerable segment, which mainly resided in rural area. Notably, the procedure to use JKN at the referral health facility was widely perceived as complicated, particularly by those of rural participants. Complaints regarding the three-tier referral system have also been repeatedly reported, mainly due to its rigid mechanism that decreases health-care facility choice flexibility and reduces employee productivity while increasing costs and health risks (Handayani et al., 2018). These are also among the reasons why informal workers hesitate to self-enroll in the JKN (Dartanto et al., 2016; Kartika, 2015) and might contribute to the high prevalence of traditional medicine use among informal workers in this study. Even though insurance may ease the financial burden and primary care facilities maybe conveniently located, these factors might be inadequate to overcome the other barriers to access associated with the JKN procedure at healthcare facilities, such as long waiting time, short working hours, and complicated referral system (Ekawati et al., 2017; Penchansky \& Thomas, 1981).

The findings from this study revealed that people's experience and personal attributes related to TM were the 
underlying factors of a person's decision to use TM, even though they were covered by health insurance. Results of this study make several contributions to our understanding of TM use. Considering the constant effort of policymakers to improve the JKN system, it crucial that we understand why a significant portion of the population remains outside the conventional healthcare system and may identify the areas where the current health care system may be failing to adequately meet people's health care needs. The results would provide deeper insight into the multitude of forces at play in the interaction between traditional and conventional medicines and help forge better integration at the institution level.

\section{Limitations of This Study}

The findings of this study should be interpreted in the context of the following three limitations. First, the cross-sectional nature prevents drawing a definitive conclusion regarding the causal relationship between the associated variables and TM use. Second, the reliance on self-report may weaken the internal validity due to the possibility of a recall bias. Third, the classification of users and non-users of TM may also pose a problem. Participants classified as TM users probably included infrequent or irregular users because the information about frequency and duration of use was not assessed. Therefore, future studies examining predictors of traditional health care use need to consider the frequency of use in a certain period so that infrequent/irregular users are distinguished from those frequent/regular users. Factors affecting the utilization of JKN by insured TM users are another significant area of interest for future studies.

\section{Conclusion}

A significant portion of rural and urban communities in Indonesia continues to rely on TM even when healthcare services have become more easily available under the universal healthcare insurance system - JKN. Being a rural resident, more educated, experiencing health problems, holding a holistic view of health, having knowledge and favourable perception of TM serve as significant predictors of TM use. This study highlights that people's experience and personal attributes related to TM, such as beliefs about health, knowledge, perception, or attitude toward TM, rather than dissatisfaction with conventional care, were largely responsible for the pervasive use of TM. The finding that TM users are no more dissatisfied with healthcare services than nonusers also implies the underutilisation of JKN services by the insured TM users living in rural areas. Given the prevalent use and favourable perception of TM, providing scientific evidence on the safety and efficacy of TM should become a major focus of the national public health agenda. Furthermore, as the policymakers and health care practitioners debate on integrating TM in the JKN system, considering the community's strong preferences for TM, this paper argues that its inclusion in the JKN system may increase the utilisation of the JKN service. That would be the best way people can better afford necessary and desired healthcare services - a fundamental element of the UHC.

\section{Acknowledgements}

This work was supported by JSPS KAKENHI (grant Number JP19KK0166). The authors would like to thank Ms. Raissa Purwaningtyas from midwifery education of Airlangga University and enumerators from Politeknik Kesehatan Kemenkes Bandung who skillfully support the data collection process.

\section{Competing Interests Statement}

The authors declare that there are no competing or potential conflicts of interest.

\section{References}

Aday, L. A., \& Andersen, R. M. (2005). Health Care Utilization and Behavior, Models of. Encyclopedia of Biostatistics, 2-5. https://doi.org/10.1002/0470011815.b2a4a010

Agyemang-Duah, W., Peprah, C., \& Arthur-Holmes, F. (2020). Predictors of healthcare utilisation among poor older people under the livelihood empowerment against poverty programme in the Atwima Nwabiagya District of Ghana. BMC Geriatrics, 20(1), 1-12. https://doi.org/10.1186/s12877-020-1473-8

Allabi, A. C., Busia, K., Ekanmian, V., \& Bakiono, F. (2011). The use of medicinal plants in self-care in the Agonlin region of Benin. Journal of Ethnopharmacology, 133(1), 234-243. https://doi.org/10.1016/j.jep.2010.09.028

Astin, J. A. (1998). Why patients use alternative medicine: Results of a national study. Journal of the American Medical Association, 279(19), 1548-1553. https://doi.org/10.1001/jama.279.19.1548

Avina, R. L., \& Schneiderman, L. J. (1978). Why patients choose homeopathy. Western Journal of Medicine, 128(4), 366-369.

Aziz, Z., \& Tey, N. P. (2009). Herbal medicines: Prevalence and predictors of use among Malaysian adults. Complementary Therapies in Medicine, 17(1), 44-50. https://doi.org/10.1016/j.ctim.2008.04.008 
Bishop, F. L., \& Lewith, G. T. (2010). Who uses CAM a narrative review of demographic characteristics and health factors associated with CAM use. Evidence-Based Complementary and Alternative Medicine, 7(1), 11-28. https://doi.org/10.1093/ecam/nen023

BPJS Health. (2019). Info BPJS Kesehatan: Pemanfaatan Data JKN Untuk Perbaikan Sistem Kesehatan di Indonesia. Retrieved Maret 14, 2019 from https://bpjs-kesehatan.go.id/bpjs/

Caniago, I., \& Siebert, S. F. (1998). Medicinal plant ecology, knowledge and conservation in Kalimantan, Indonesia. Economic Botany, 52(3), 229-250. https://doi.org/10.1007/BF02862141

Chaerani, S., \& Amar, D. (2010). Gunem Catur in the Sunda Region of West Java: Indigenous Communication on MAC Plant Knowledge and Practice within the Arisan in Lembang, Indonesia. (Publication No. 6) [Doctoral dissertation, Leiden University]. Leiden University Library.

Clement, Y. N., Morton-Gittens, J., Basdeo, L., Blades, A., Francis, M. J., Gomes, N., Janjua, M., \& Singh, A. (2007). Perceived efficacy of herbal remedies by users accessing primary healthcare in Trinidad. BMC Complementary and Alternative Medicine, 7, 1-9. https://doi.org/10.1186/1472-6882-7-4

Dartanto, T., Rezki, J. F., Pramono, W., Siregar, C. H., \& Bintara, H. (2016). Why Are Workers in the Informal Sector Reluctant to Join the National Health Insurance System in Indonesia? Journal of Southeast Asian Economies, 33(3), 320-348. https://doi.org/10.1355/ae33-3c

Dartanto, T., Rezki, J. F., Siregar, C. H., Bintara, H., \& Pramono, W. (2015). Expanding Universal Health Coverage in The Presence of Informality in Indonesia : Challenges and Policy (LPEM-FEUI working Paper No. 004). Retrieved from LPEM-UI website: https://www.lpem.org/expanding-universal-health-coverage-in-the-presence-of-informality-in-indonesia-cha llenges-and-policy-implications/

Delgoda, R., Ellington, C., Barrett, S., Gordon, N., Clarke, N., \& Younger, N. (2004). The practice of polypharmacy involving herbal and prescription medicines in the treatment of diabetes mellitus, hypertension and gastrointestinal disorders in Jamaica. West Indian Medical Journal, 53(6), 400-405.

Ekawati, F. M., Claramita, M., Hort, K., Furler, J., Licqurish, S., \& Gunn, J. (2017). Patients' experience of using primary care services in the context of Indonesian universal health coverage reforms. Asia Pacific Family Medicine, 3(1), 4. https://doi.org/10.1186/s12930-017-0034-6

Elfahmi, Woerdenbag, H. J., \& Kayser, O. (2014). Jamu: Indonesian traditional herbal medicine towards rational phytopharmacological use. Journal of Herbal Medicine, 4(2), 51-73. https://doi.org/10.1016/j.hermed.2014.01.002

Furnham, A., \& Kirkcaldy, B. (1996). The health beliefs and behaviours of orthodox and complementary medicine $\begin{array}{lllll}\text { clients. British Journal of Clinical Psychology, } & \text { 35(1), }\end{array}$ https://doi.org/10.1111/j.2044-8260.1996.tb01161.x

Gyasi, R., Buor, D., Adu-Gyamfi, S., Adjei, P. O. W., \& Amoah, P. A. (2018). Sociocultural hegemony, gendered identity, and use of traditional and complementary medicine in Ghana. Women and Health, 58(5), 598-615. https://doi.org/10.1080/03630242.2017.1321608

Gyasi, R. M., Asante, F., Abass, K., Yeboah, J. Y., Adu-Gyamfi, S., \& Amoah, P. A. (2016). Do health beliefs explain traditional medical therapies utilisation? Evidence from Ghana. Cogent Social Sciences, 2(1). https://doi.org/10.1080/23311886.2016.1209995

Gyasi, R. M., Mensah, C. M., Adjei, P. O.-W., \& Agyemang, S. (2011). Public Perceptions of the Role of Traditional Medicine in the Health Care Delivery System in Ghana. Global Journal of Health Science, 3(2), 40-49. https://doi.org/10.5539/gjhs.v3n2p40

Gyasi, R. M., Mensah, C. M., \& Siaw, L. P. (2015). Predictors of Traditional Medicines Utilisation in the Ghanaian Health Care Practice: Interrogating the Ashanti Situation. Journal of Community Health, 40(2), 314-325. https://doi.org/10.1007/s10900-014-9937-4

Handayani, P. W., Saladdin, I. R., Pinem, A. A., Azzahro, F., Hidayanto, A. N., \& Ayuningtyas, D. (2018). Health referral system user acceptance model in Indonesia. Heliyon., 4, e01048. https://doi.org/10.1016/j.heliyon.2018.e01048

Hollenberg, D., Lytle, M., Walji, R., \& Cooley, K. (2013). Addressing provider shortage in underserviced areas: The role of traditional, complementary and alternative medicine (TCAM) providers in canadian rural healthcare. European Journal of Integrative Medicine, 5(1), 15-26. https://doi.org/10.1016/j.eujim.2012.08.008

Hughes, G. D., Aboyade, O. M., Clark, B. L., \& Puoane, T. R. (2013). The prevalence of traditional herbal 
medicine use among hypertensives living in South African communities. BMC Complementary and Alternative Medicine, 13. https://doi.org/10.1186/1472-6882-13-38

James, P. B., Wardle, J., Steel, A., \& Adams, J. (2019). Pattern of health care utilization and traditional and complementary medicine use among Ebola survivors in Sierra Leone. PLoS ONE, 14(9), 1-19. https://doi.org/10.1371/journal.pone.0223068

Jennifer, H., \& Saptutyningsih, E. (2015). Preferensi individu terhadap pengobatan tradisional di Indonesia. Jurnal $\begin{array}{lllll}\text { Ekonomi Dan Studi Pembangunan, } & \text { 16(1), }\end{array}$ https://doi.org/https://doi.org/10.18196/jesp.2015.0039.26-41

Kartika, D. M. (2015). Does Indonesian National Health Insurance serve a potential for improving health equity in favour of workers in informal economy? (Publication No. 72112) [Doctoral dissertation, LSE]. MPRA.

Kasumaningrum, Y. (2019). 16 Percent of West Java Residents Unregistered as BPJS Health Participants. Retrieved December $\quad 2, \quad 2019$ from https://www.pikiran-rakyat.com/bandung-raya/pr-01310134/16-persen-penduduk-jabar-belum-jadi-pesertabpjs-kesehatan

Kelner, M., \& Wellman, B. (1997). Health care and consumer choice: Medical and alternative therapies. Social Science and Medicine, 45(2), 203-212. https://doi.org/10.1016/S0277-9536(96)00334-6

Kuo, G. M., Hawley, S. T., Weiss, L. T., Balkrishnan, R., \& Volk, R. J. (2004). Factors associated with herbal use among urban multiethnic primary care patients: A cross-sectional survey. BMC Complementary and Alternative Medicine, 4(18). https://doi.org/10.1186/1472-6882-4-18

Lee, G. B. W., Charn, T. C., Chew, Z. H., \& Ng, T. P. (2004). Complementary and alternative medicine use in patients with chronic diseases in primary care is associated with perceived quality of care and cultural beliefs. Family Practice, 21(6), 654-660. https://doi.org/10.1093/fampra/cmh613

Liebert, M. A. (1998). Characteristics of users and nonusers of alternative medicine in dermatologic patients attending a university hospital clinic: a short report. J Altern Complement Med, 4(3), 277-279. https://doi.org/10.1089/acm.1998.4.3-277

Lim, M. A., \& Pranata, R. (2020). The insidious threat of jamu and unregulated traditional medicines in the COVID-19 era. Diabetes and Metabolic Syndrome: Clinical Research and Reviews, 14(5), 895-896. https://doi.org/10.1016/j.dsx.2020.06.022

Mcgregor, K. J., \& Peay, E. R. (1996). The choice of alternative therapy for health care: Testing some propositions. Social Science and Medicine, 43(9), 1317-1327. https://doi.org/10.1016/0277-9536(95)00405-X

$\mathrm{MoH}$ of Indonesia. (2010). RISKESDAS 2010. Retrieved from https://www.litbang.kemkes.go.id/laporan-riset-kesehatan-dasar-riskesdas/

$\mathrm{MoH}$ of Indonesia. (2013). RISKESDAS 2013. Retrieved from https://www.litbang.kemkes.go.id/laporan-riset-kesehatan-dasar-riskesdas/

$\mathrm{MoH}$ of Indonesia. (2018). Hasil Utama Riskesdas 2018 (Basic Health Survey 2018). Retrieved from https://www.litbang.kemkes.go.id/laporan-riset-kesehatan-dasar-riskesdas/

$\mathrm{MoH}$ of Indonesia. (2020). Profil Kesehatan Indonesia Tahun 2019. Retrieved from https://pusdatin.kemkes.go.id/resources/download/pusdatin/profil-kesehatan-indonesia/Profil-Kesehatan-ind onesia-2019.pdf

Patwardhan, B., Warude, D., Pushpangadan, P., \& Bhatt, N. (2005). Ayurveda and traditional Chinese medicine: A comparative overview. Evidence-Based Complementary and Alternative Medicine, 2(4), 465-473. https://doi.org/10.1093/ecam/neh140

Peltzer, K., Pengpid, S., Puckpinyo, A., Yi, S., \& Anh, L. V. (2016). The utilization of traditional, complementary and alternative medicine for non-communicable diseases and mental disorders in health care patients in Cambodia, Thailand and Vietnam. BMC Complementary and Alternative Medicine, 16(1), 1-12. https://doi.org/10.1186/s12906-016-1078-0

Penchansky, R., \& Thomas, J. W. (1981). The concept of access: Definition and relationship to consumer satisfaction. Medical Care, 19(2), 127-140. https://doi.org/10.1097/00005650-198102000-00001

Pengpid, S., \& Peltzer, K. (2018). Utilization of traditional and complementary medicine in Indonesia: Results of a national survey in 2014-15. Complementary Therapies in Clinical Practice, 33, 156-163. https://doi.org/10.1016/j.ctcp.2018.10.006

Picking, D., Younger, N., Mitchell, S., \& Delgoda, R. (2011). The prevalence of herbal medicine home use and 
concomitant use with pharmaceutical medicines in Jamaica. Journal of Ethnopharmacology, 137(1), 305-311. https://doi.org/10.1016/j.jep.2011.05.025

Putro, W. R., Utomo, R. D. W., \& Achmad, S. (2020). Analisis Elemen Visual Pada Desain Kemasan Produk Jamu Houseblend Suwe Ora Jamu. Jurnal Seni \& Reka Rancang, 2(2), 253-263. Retrieved from https://trijurnal.lemlit.trisakti.ac.id/jsrr/article/view/8238

Quinlan, M. B., \& Quinlan, R. J. (2007). Modernization and Medicinal Plant Knowledge in a Caribbean Horticultural Village. International Journal of Qualitative Studies on Health and Well-Being, 21(2), 169-192. https://doi.org/10.1525/MAQ.2007.21.2.169.169

Rahayu, Y. Y. S., Araki, T., \& Rosleine, D. (2020). Factors affecting the use of herbal medicines in the universal health coverage system in Indonesia. Journal of Ethnopharmacology, 260, 112974. https://doi.org/10.1016/j.jep.2020.112974

Sato, A., \& Costa-i-Font, J. (2012). Does culture matter at all in explaining why people still use traditional medicines? (LSE Working No. 27). Retrieved from LSE website: http://eprints.lse.ac.uk/43653/1/LSEHWP27.pdf

Schäfer, T., Riehle, A., Wichmann, H. E., \& Ring, J. (2002). Alternative medicine in allergies-Prevalence, patterns of use, and costs. Allergy: European Journal of Allergy and Clinical Immunology, 57(8), 694-700. https://doi.org/10.1034/j.1398-9995.2002.23469.x

Supardi, S., Herman, M. J., \& Yuniar, Y. (2011). Utilization of Traditional Medicine in Self-medication Practise in Indonesia (Analysis of RISKESDAS Data in 2010). Buletin Penelitian Sistem Kesehatan, 14(4), 375-381.

Toda, M., Masuda, M., \& Rengifo, E. L. (2017). Medicinal Plant Use Influenced by Health Care Service in Mestizo and Indigenous Villages in the Peruvian Amazon. Journal of Sustainable Development, 10(3), 19-34. https://doi.org/10.5539/jsd.v10n3p19

Trotter, R. (1981). Remedios caseros: Mexican American home remedies and community health problems. Soc Sci Med, 15B, 107-114.

Vandebroek, I., \& Balick, M. J. (2012). Globalization and loss of plant knowledge: Challenging the paradigm. PLoS ONE, 7(5), e37643. https://doi.org/https://doi.org/10.1371/journal.pone.0037643

Vincent, C., \& Furnham, A. (1996). Why do patients turn to complementary medicine? An empirical study. British Journal of Clinical Psychology, 35(1), 37-48. https://doi.org/10.1111/j.2044-8260.1996.tb01160.x

Weckmüller, H., Barriocanal, C., Maneja, R., \& Boada, M. (2019). Factors Affecting Traditional Medicinal Plant Knowledge of the Waorani, Ecuador. Sustainability, 11(16), e4460. https://doi.org/10.3390/su11164460

WHO. (1978). Declaration of Alma-Ata. International conference on primary health care. Retrieved from https://www.who.int/publications/almaata_declaration_en.pdf

WHO. (2000). General Guidelines for Methodologies on Research and Evaluation of Traditional Medicine World Health Organization. Retrieved from http://apps.who.int/iris/bitstream/handle/10665/66783/WHO_EDM_TRM_2000.1.pdf;jsessionid=F6341AF 5F563A02C2345C742055C9524? sequence $=1$

WHO. (2013). The world health report 2013: Research for Universal Health Coverage. Retrieved from https://www.afro.who.int/publications/world-health-report-2013-research-universal-health-coverage

Wiles, J., \& Rosenberg, M. W. (2001). 'Gentle caring experience.' Health \& Place, 7(3), 209-224. https://doi.org/10.1016/s1353-8292(01)00011-9

Wilson, S. L., Kratzke, C., \& Hoxmeier, J. (2012). Predictors of access to healthcare: what matters to rural Appalachians? Global Journal of Health Science, 4(6), 23-35. https://doi.org/10.5539/gjhs.v4n6p23

\section{Copyrights}

Copyright for this article is retained by the author(s), with first publication rights granted to the journal.

This is an open-access article distributed under the terms and conditions of the Creative Commons Attribution license (http://creativecommons.org/licenses/by/4.0/). 